NAmES, Vol. 67 No. 4, December 2019, 185-198

Check for updates

\title{
Names and Identities in Courtroom Narratives
}

\author{
Krisda Chaemsaithong
}

Department of English Language and Literature, Hanyang University, Seoul, South Korea

This study seeks to examine how the use of names serves to accomplish the process of identity construction in institutional discourse. Drawing upon six opening addresses from three high-profile trials, the study analyzes the forms, functions, and frequency of names that lawyers use to refer to defendants and victims in their narratives. The quantitative and qualitative analysis reveals that the prosecution and the defense differ starkly in how they use names to construct the identities of the characters. Such systematic differences contribute to ascribing polarized identities to the characters, which in effect negotiates reality by (de)legitimizing guilt and responsibility claims and mediating jurors' perceptions.

KEYWORDS courtroom, identity, legal, narratives, name, opening address

\section{Introduction}

That personal names function as identity bearers is well acknowledged. Names have been shown to embody socio-cultural aspects of the referent, including gender, social class, and age (Gerritzen 1999; Van Langendonck 2007). However, recent views hold that identity does not lie inside a self or in pre-established labels. Rather, it is fluid, locally occasioned and is constructed and negotiated in discursive practices (De Fina 2003; Bucholtz and Hall 2005; De Fina, Schiffrin, and Bamberg 2006). Names are not mere labels with inherent properties that identify individuals, but they also allow language users to manage identity work (Ainiala and Ostman 20I7, IO-II), express (dis)affiliation (Clayman 20I0), and establish interpersonal relationships (Mondada 2004; Aldrin 20I8). This view of names as "doing" words is an area that calls for a deeper understanding of how naming aids in the process of identity construction and negotiation from moment to moment, and how names may be used to mediate an audience's perceptions and experiences during an interaction (Aldrin 2016). 
The current study explores how onomastic choices become a high-stakes linguistic resource for lawyers to manage the identities of the characters in their narratives, and how emerging identities in turn effect negotiation of reality and legitimize guilt claims, thereby mediating jurors' perceptions of the named individuals. In this institutional setting, lawyers (re)present and (re)construct basically the same sequence of events involving the same set of social actors. In doing so, they strive to cast doubt on each other's version and seek to control and manage the opposing side's contributions. This clash between the proponents of conflicting views is believed to determine the truth and deliver justice for all. Given its adversarial nature, "what happens in the courtroom depends crucially on how people are characterized by others, on how they characterize themselves, and on the features of themselves as individuals that are made relevant during the course of an interaction" (McKinlay and McVittie 20I I, I24). During this process, identity (de)construction becomes a contested practice that potentially affects a trial's outcome (Matoesian 200I; D'hondt 20I0). In particular, based on three high-profile criminal American trials, this study attends to the opening event-an uninterrupted monologic narrative addressed to the jury-with the legal aim of presenting an overview or a "road map" of the case to the jury. This initial phase of courtroom talk is not only the counsel's first opportunity to manage the impressions of characters in their narratives but, more importantly, also has been found to influence the jurors in drawing tentative conclusions (Lind and Ke I985; Pennington and Hastie r991; Spiecker and Worthington 2003). The combined quantitative and qualitative analysis endeavors to answer the following questions: (I) what are the forms, functions, and frequencies of names lawyers use to position the characters in their narratives?; (2) how does the use of names index the presenter's ideological position and communicative goals?; and (3) to what extent do the prosecution and defense differ in their use of names? It will be shown how naming practices construct polarized identities of the same characters in their narratives and, in effect, mediate jurors' perceptions by (de)legitimizing guilt and responsibility claims. This study contributes not only to revealing the complex, intertwined relationships between names, identity, and speakers' goals. It also puts into practice the social-constructivist approach to identity in onomastic studies.

The analysis unfolds in several parts. First I discuss the relationships between names and their roles in establishing and attributing identities. I then provide some background to the cases under investigation and proceed to present the findings for the defendants and victims. The conclusion reflects on how different identities enacted through naming serve in the meaning-making process and shape perceptions in courtroom discourse.

\section{Names and Identity}

From a functional linguistic perspective, every time we use language, we make lexico-grammatical choices from sets of available options to fulfill a 
communicative goal in a specific context (Halliday and Hasan I989). Chief among the choices we (have to) choose from are various forms of person reference. Allerton (I996) distinguishes two typical choices: proper noun phrases (e.g. Mr. Major) and descriptive noun phrases (e.g. that guy next door), or sometimes a hybrid of the two. The former category is the focus of this study.

Schegloff (2007, I 24) predicts that for initial mention of a person, English speakers will by default choose "first name only" because this format is a "referring simpliciter" (i.e. minimal and recognizable reference). However, other scholars (e.g. Levinson 2007; Anchimbe 20II) note additional constraints that are in operation, such as preferential use of kin terms for senior kin, avoidance of the first names of the co-present parties in some cultures, and restricted use of personal names in some cultures. Thus, which choice is selected appears to be socially, rather than lexically, determined (Murphy I988; Dickey I997) and can reflect a speaker's ideological position. When individuals are nominated by proper names, they are personalized, and their unique identity and human characteristics are highlighted (Van Leeuwen 2008). Proper names may vary in terms of formality, from very formal (last name only), semi-formal (first and last), informal (first name only) to least formal (nickname). Nominations may also be titulated, such as Doctor $X$ and Professor of Linguistics at $X$ University. Informal nominations without titles may be selected to de-authorize and delegitimize the power and status of the referent to strengthen the assertion of the speaker, while formal nominations with a titulation do just the opposite (Hart 2OII). As evidence, trial practice manuals recommend lawyers to refer to an opposition witness by their role, first name, and last name (e.g. Defendant Lee Boyd Malvo) in order to "distance [themselves] from" that witness (O'Barr I982, 34), while only first names are recommended for personalizing purposes. Examining the closing arguments of a rape case, Rosulek (2008) finds that the prosecution refers to a victim with a nickname, while the defense uses her full first and last name. It is argued that the nickname functions as a diminutive. Along with reference to her young age, the prosecution's choice "twelve-year-old Lizzy" constitutes a strategy that sets her up as childlike and personal to the jury, while the defense's choices (for example, Eliza and Eliza Smith) make her more distant and removed from the jurors. Just as ideologically significant, when the speaker chooses not to name a referent in the discourse, this suppression may omit or gloss over the role and responsibility of that individual.

A few previous studies on the use of names in the courtroom inform the present study. In discussing the prosecutor's closing argument, Conley (2016) notes that he seldom refers to the defendant by name but focuses on the details of the crime. In contrast, names are frequently used to refer to the victims, thereby "bringing them, as individuals, into the jurors" focus (I38). Similarly, Rosulek (2008, 2015) finds that in closing arguments the prosecution references the defendant more frequently than the defense does, and the defense sometimes silences or erases the defendant from their discourse. In addition, while the prosecution refers to the person on trial as "the defendant", the defense lawyer 
foregrounds the unique identity of the defendant by often using semi-formal or formal nominations, thereby calling attention to the defendant as a real person. The researcher acknowledges that more work is needed to determine if these patterns hold in other trials and in other courtroom genre.

\section{Data and Methodology}

The data consists of official transcripts from three high-profile American trials, hence six opening events in total. These cases were selected because of their high visibility. This type of case differs from others in that it often taps into sensitive issues in society (such as sexual abuse in school or acts of terrorism) so that the jurors may already harbor stronger opinions about the culpability of the defendant because they have learned about the case before the trial begins. ${ }^{\mathrm{I}}$ In mass killing cases, for example, the jury has usually heard from the media and from witness after witness who has lost loved ones to the alleged terrorist's barbarity. This complicates the purpose of the judicial process to rise above the instinctive desire for vengeance and determine what is just and humane. These trials also deal with psychological issues that go to the heart of the search for truth, such as the reliability of eyewitness testimony or the likelihood that a person can be "brainwashed" into committing a violent crime. Owing to these factors, the outcome of the trials is difficult for the public, even the attorneys involved, to predict; and the identity of the characters in courtroom narratives is of critical importance in persuading the jurors. These cases, therefore, constitute rich resources for analyzing how the presenter's goals, understandings, and biases are reflected in the discourses they create. Descriptions for the cases under examination are summarized below.

Case I: 2002 D.C. sniper attacks (Prosecution 5,60I words; Defense I 4,086 words)

This case involves a series of coordinated shootings that killed ten people and critically injured three others during three weeks in October 2002 in the states of Maryland and Virginia, and the District of Columbia. Travelling in a blue, I990 Chevrolet sedan, the shooters-John Muhammad (aged 4I then) and Lee Boyd Malvo (aged I7 then)-chose targets at random. Muhammad had befriended the juvenile Malvo (who regarded Muhammad as a father figure) and enlisted him in the attacks. Malvo allegedly was tied to the crimes by DNA and fingerprint evidence as well as a lengthy taped confession in which he boasted of the killings and laughed at the dead. The defense argued that Malvo was brainwashed by Muhammad into committing the crimes, while the prosecution attempted to depict Malvo as a rational adult who knew the difference between right from wrong.

Case 2: 20I 2 Penn State child sex abuse (Prosecution 8,437 words; defense 5,260 words)

This mass sexual abuse case features an assistant football coach at Pennsylvania State University, Gerald Sandusky, who allegedly engaged in the 
sexual abuse of young boys over a I 5-year period (from 1994 to 2009). The defendant is said to have located and groomed the victims through his charity organization, The Second Mile, which was founded to help disadvantaged youth. In 2009, Victim I's mother reports the sexual assault of her son, prompting the Pennsylvania Attorney General to begin an investigation. In November 20II, Sandusky was arrested and charged with sexually abusing eight boys, including one in a shower on campus a decade before. This incident had been witnessed by a young graduate assistant who informed the head coach and two campus administrators, none of whom contacted the authorities. Interestingly, in this case, there was no physical evidence, only witness accounts. The prosecution therefore relied on testimony from accusers and eye-witnesses to portray the defendant as a "serial predatory pedophile". The defense refuted that characterization and instead made the case that Sandusky was a father figure who had helped a great number of underprivileged children and was the victim of a few accusers who lied for financial compensation.

Case 3: 2013 Boston Marathon bombing (Prosecution 7,525 words; defense 2,305 words)

This terrorist attack took place a short distance from the finish line of the annual Boston Marathon event, held on April I5, 20I3. The marathon had more than 26,000 runners participating in the race and hundreds of thousands of spectators. A pair of homemade bombs detonated in the crowd watching the race, killing three people and injuring hundreds. Two suspects were later identified as brothers: I9-year-old Dzhokhar Tsarnaev and 26-year-old Tamerlan Tsarnaev. While trying to escape from Boston, the two murdered an MIT campus police officer, Sean Collier, to take his gun and also carjacked a driver in Cambridge. Tamerlan was wounded and later died due to his injuries. Dzhokhar was found hiding in a boat in a suburb of Boston. During questioning, Dzhokhar alleged that he and his brother were motivated by extremist Islamist beliefs and the wars in Iraq and Afghanistan. He stated that they had been self-radicalized and were unconnected to any outside terrorist. He alleged that he had been following his brother's lead. He also claimed that they had learned to build explosive devices from an online magazine of the al-Qaeda affiliate in Yemen. The prosecutor held Dzhokhar to be as guilty and responsible as his brother. The defense attorney, while admitting that the defendant had placed the second bomb and had been present during the murder of the police officer and the carjacking, argued that the defendant had fallen under the influence of his brother and asked the jury show understanding for the young man's situation and rule with mercy.

The quantitative methodology was performed as follows. Names referring to the defendants and the victims in each case were counted and classified based on their form. For this study, all the frequency counts were normalized to a common basis of I0,000 words, to allow for comparison of the results for different lengths of text. A qualitative analysis was then performed to investigate 
in detail how the use of these names was pragmatically motivated, how the underlying ideologies of each side were indexed, and how those choices aided in shaping the jurors' perceptions.

\section{Results}

\section{Quantitative Findings}

The overall frequencies of the nominated references of the defendants, displayed in Table I, indicate the opposing strategies across the trials. The defendant is suppressed in the prosecution's speech but is foregrounded in the defense's, as evidenced by the frequencies of the nominated references. References to the victims, also shown in the same table, indicate two consistent contrasting strategies: foregrounding of the victims in the prosecution's speech and backgrounding in the defense's.

While the frequency counts reveal systematic differences in the reference patterns between the two sides, the differences go beyond sheer frequencies as they have to do with the specific reference choices each side chooses as explained below.

\section{Qualitative Findings}

Reference to the defendants

Case I. As Table 2 shows, the defense in Case I uses nominations much more frequently and variably than the prosecution does. Of note is the highest occurrence of the informal first name Lee. In a formal context like a courtroom, first names may help to create solidarity with the referent-an identity that is likely to secure a positive outcome with the defense. This in effect strengthens the claim that the defendant is a naïve minor vulnerable to manipulation. Such an informal label occurs throughout the trial but is concentrated in the defense's narrative about the defendant's childhood until the time he met Muhammad.

What serves as evidence that the use of the first name is a purposeful strategy is the co-occurrence of a more formal title to refer to the defendant's accomplice-John Muhammad, illustrated in example (I):

TABLE 1

OVERALL FREQUENCIES OF NOMINATED REFERENCES OF THE DEFENDANTS AND VICTIMS

\begin{tabular}{lcrrr}
\hline & \multicolumn{2}{c}{ Defendant } & \multicolumn{2}{c}{ Victim } \\
\cline { 2 - 4 } \cline { 2 - 4 } & Pro & \multicolumn{1}{c}{ Def } & Pro & Def \\
\hline Case 1 & $7.14^{3}$ & 99.39 & 46.42 & 2.84 \\
Case 2 & 7.12 & 121.65 & 129.19 & 20.91 \\
Case 3 & 1.33 & 95.45 & 98.34 & 21.70 \\
Total & 15.59 & 316.49 & 273.95 & 45.45 \\
\hline
\end{tabular}


TABLE 2

NOMINATION OF THE DEFENDANT IN CASE 1

\begin{tabular}{|c|c|c|c|c|}
\hline & Prosecution & Frequencies & Defense & Frequencies \\
\hline Informal (given name) & & & Lee & 87.32 \\
\hline \multirow{4}{*}{$\begin{array}{l}\text { Semi-formal (given } \\
\text { and surname) }\end{array}$} & & & Lee Malvo & 8.52 \\
\hline & & & Linberg Williams & 1.42 \\
\hline & & & John Lee Muhammad & 0.71 \\
\hline & & & Lee Boyd Malvo & 0.71 \\
\hline \multirow[t]{2}{*}{ Formal (surname) } & Malvo & $5 \cdot 36$ & Malvo & 0.71 \\
\hline & Mr. Malvo & 1.78 & & \\
\hline \multicolumn{5}{|l|}{$\begin{array}{l}\text { Titulated formal } \\
\text { (title + last name) }\end{array}$} \\
\hline Total & & 7.14 & & $99 \cdot 39$ \\
\hline
\end{tabular}

I. It starts with the attention that John Muhammad pays to Lee and goes to the loss of John Muhammad's children. It goes through the taking, the physical taking of Lee going and bringing Lee into John Muhammad's home. It goes to the militaristic training of Lee by John Muhammad ... (Pro)

Semi-formal nominations are used to a much lesser extent. Of these, Lee Malvo is the most frequent. It appears in more formal contexts, such as in metadiscursive discussion of legal charges seen in example (2). When used in combination with the last name, it lends power and helps to construct an identity that supports the defense's claim that the defendant was not himself when committing criminal acts in example (3).

2. We, on the other hand, have the burden to prove that Lee Malvo was under a degree of indoctrinization ... So don't expect us to be putting on evidence that there's some other part other than Lee Malvo. (Def)

3. The prosecutor in his opening statement has described to you 23 days in the life of Lee Malvo. Those 23 days he wasn't Lee Malvo. He will tell you through those tapes that he was John Lee Muhammad, son of John Muhammad. I would like to introduce you to the real Lee Malvo. (Def)

The prosecution's discourse, as exhibited in examples (2) and (3) above, exhibits no instance of reference by the defendant's first name. As example (4) shows, through formal nominations (Malvo or Mr. Malvo), the prosecutor not only creates deictic distance between the defendant and the jurors, but also shapes the identity of the defendant as an adult who has an equal share of responsibility in the crime. This linguistic tactic is exemplified in $(4)$.

4. Mr. Malvo was asleep in the front seat of that automobile [used as the base for the attacks] ... It was at this shooting that the intent of Malvo became clear. (Pro) 
TABLE 3

NOMINATION OF THE DEFENDANT IN CASE 2

\begin{tabular}{|c|c|c|c|c|}
\hline & \multicolumn{2}{|c|}{ Prosecution } & \multicolumn{2}{|c|}{ Defense } \\
\hline & Example & Frequency & Example & Frequency \\
\hline Informal (given name) & & & Jerry & 60.84 \\
\hline $\begin{array}{l}\text { Semi-formal (given } \\
\text { and surname) }\end{array}$ & Jerry Sandusky & 5.93 & Jerry Sandusky & 55.11 \\
\hline Formal (surname) & & & & \\
\hline $\begin{array}{l}\text { Titulated formal } \\
\quad \text { (title + last name) }\end{array}$ & Mr. Sandusky & 1.19 & Mr. Sandusky & 5.70 \\
\hline Total & & 7.12 & & 121.65 \\
\hline
\end{tabular}

Case 2. As in Case I, the prosecutor in Case 2 avoids referring to the defendant by name, and this practice stands in stark contrast to the defense. More specifically, as Table 3 shows, the prosecution uses no informal nominations, a few semi-formal nominations, and one titulated formal nomination. By contrast, the defense employs informal and semi-formal references to a much higher degree.

Co-occurring with evidentials ${ }^{2}$, the semi-formal nominations in the prosecutor's speech serve to legitimize the identity claim that the defendant was involved in sexual molestation. In ( $5 \mathrm{a})$, the lawyer first introduces the defendant through a descriptive noun phrase but immediately supplies an appositive semiformal nomination to identify whom the witness saw. In ( $5 \mathrm{~b})$, the defendant's name appears in an it-cleft construction that again emphatically identifies the person Coach Miller saw embrace the victim.

(5a) He told his coworkers and they didn't know what to do. They saw the defendant, Jerry Sandusky, all the time with little boys. (Pro)

(5b) He [Coach Miller] saw Aaron [victim] ... wrapped in the embrace of the defendant who popped up and Coach Miller will tell you, Oh, I'm just showing him some wrestling moves. Coach Miller will say it didn't look like anything I [Coach Miller] ever seen. It was Jerry Sandusky. He thought that was weird. (Pro)

The only instance of titulated reference occurs in direct reported speech, shown in (6), which may as well be the witness's choice of reference, as opposed to the prosecutor's. Interestingly, following the reported clause, the lawyer immediately switches to a descriptive reference, "the defendant".

(6) You will hear from Donald Fisher ... Donald Fisher will say 'I told Mr. Sandusky, hey, he's a growing kid. The defendant wouldn't let it go.' Three out of the five instances of the informal nominations occur in reported discourse from two of the witnesses as well. (Pro)

In contrast, informal and semi-formal nominations recur throughout the defense's narratives, in particular when he recounts the defendant's background 
TABLE 4

NOMINATION OF THE DEFENDANT IN CASE 3

\begin{tabular}{|c|c|c|c|c|}
\hline & Prosecution & Frequencies & Defense & Frequencies \\
\hline Informal (given name) & \multirow{4}{*}{ Dzhokhar Tsarnaev } & \multirow{4}{*}{1.33} & \multirow{5}{*}{$\begin{array}{l}\text { Jahar } \\
\text { Jahar Tsarnaev }\end{array}$} & 65.08 \\
\hline $\begin{array}{l}\text { Semi-formal (given } \\
\text { and surname) }\end{array}$ & & & & 30.37 \\
\hline Formal (surname) & & & & \\
\hline $\begin{array}{l}\text { Titulated formal } \\
\qquad \text { (title + last name) }\end{array}$ & & & & \\
\hline Total & & 1.33 & & 95.45 \\
\hline
\end{tabular}

or seeks to elicit a positive evaluation of the defendant. This is illustrated, respectively, in examples (7) and (8).

(7) Jerry's program, Second Mile, which he started in 1977, was founded by Jerry ... He grew up an only child. His parents loved kids but they only had Jerry ... They agree to take over a recreation center ... That's where Jerry grew up ... And Jerry got this deep-seated love for helping kids ... In I977, Jerry decided let me try to start a foster home for kids ... (Def)

(8) Jerry is hands on. Jerry, in my opinion, loves kids so much that he does things that none of us would ever dream of doing. (Def)

The titulated reference $M r$. Sandusky appears only in metadiscursive legal talk, as in the following example:

(9) The Commonwealth has overwhelming evidence against $M r$. Sandusky. (Def)

Owing to these differences, the defense is able to construct an identity of the defendant with a much more affective and familiar persona, making the accused appear to be just like "one of us".

Case 3. Finally, as shown in Table 4, what is most striking in this case is the defense's exclusive use of Jahar to refer to the defendant, the affectionate nickname by which his university friends know him. This familiar nomination is in stark contrast to his given name Dzhokhar which the prosecutor uses only once. This personalized strategy creates affinity within the courtroom.

No formal or titulated choices are employed by either side, and the defense alternates between informal nominations and semi-formal nominations without a difference. This may be attributable to two factors. The first is contextual and related to the fact that using the defendant's last name alone would not distinguish him from his brother, leaving available the informal and semiformal choices. The other is pragmatic and has to do with the presenter's ideological position. Given the defense's claim that the defendant had been under his brother's influence, the use of informal and semi-formal nominations might 
TABLE 5

NOMINATION OF THE VICTIMS IN CASE 1

\begin{tabular}{|c|c|c|c|c|}
\hline & Prosecution & Frequencies & Defense & Frequencies \\
\hline Informal (given name) & & & Mildred & 2.84 \\
\hline $\begin{array}{l}\text { Semi-formal (given } \\
\text { and surname) }\end{array}$ & $\begin{array}{l}\text { Linda Franklin, } \\
\text { James Sonny Buchanan, } \\
\text { Premkumar Walekar, } \\
\text { Pascal Charlot, Iran Brown, } \\
\text { Dean Myers, etc. }\end{array}$ & 46.42 & & \\
\hline \multicolumn{5}{|l|}{ Formal (surname) } \\
\hline \multicolumn{5}{|l|}{$\begin{array}{l}\text { Titulated formal } \\
\text { (title + last name) }\end{array}$} \\
\hline Total & & 46.42 & & 2.84 \\
\hline
\end{tabular}

help to establish solidarity and familiarity for this malleable defendant. What is interesting is that the defendant is consistently referenced less formally than his brother in the same sentence, positioning him closer to the jury. This tactic is illustrated in example (Io).

(Io) While Tamerlan Tsarnaev was looking and immersed in death and destruction and carnage in the Middle East, Jahar spent most of his time on the Internet doing things that teenagers do: Facebook, cars, girls. (Def)

In contrast to the above strategy, the prosecutor's sole nominated reference to the defendant occurs when he first introduces the defendant at the beginning of his narrative:

(II) The defendant, Dzhokhar Tsarnaev, rounded the corner onto Boylston Street and began walking towards the Boston marathon (Pro)

Interestingly, the prosecutor overwhelmingly references the defendant by the descriptive term "the defendant" (about I40 times/I0, ০০o words). This foregrounds his legal identity by concealing his individuality.

\section{Reference to the victims}

Case I. In this case, the prosecution uses nominations far more than the prosecutor does and enumerates all the major victims of the serial killings, as exemplified in Table 5. The use of first and last names not only allows the prosecution to personalize the victims individually, but also gives a glimpse into the ethnic diversities of the victims, thereby highlighting the random nature of the case and the vast extent of the damage:

(I2) The second killing ... was an Indian immigrant ... Premkumar Walekar. (Pro) 
TABLE 6

NOMINATION OF THE VICTIMS IN CASE 2

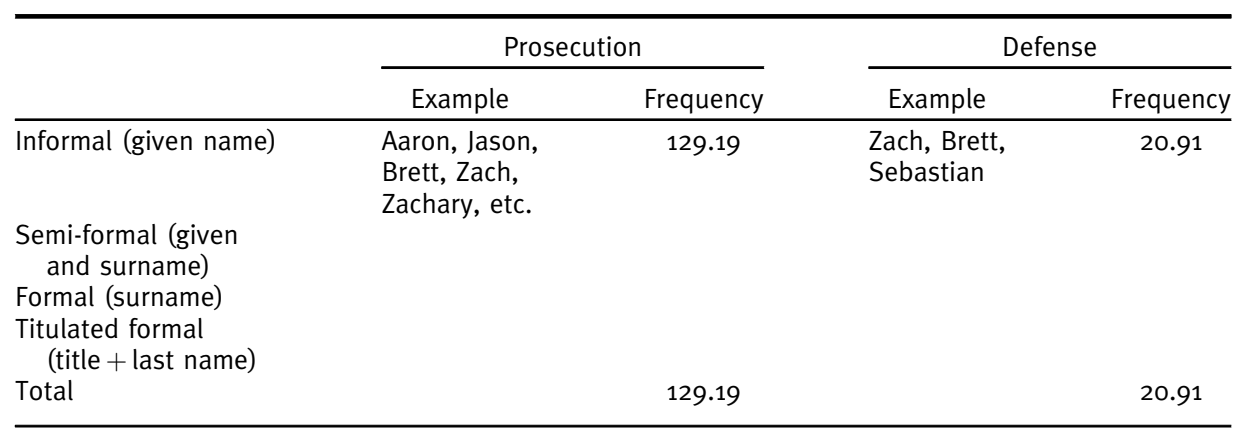

By contrast, the defense clearly avoids mentioning the victims. In those few instances he does, informal choices are used to reference Muhammad's ex-wife, Mildred, whom the defendant was allegedly assigned to check on. The probable purpose of the reference is to problematize the validity of the prosecution's claim, rather than foregrounding her as a victim.

Case 2. As in Case $\mathrm{I}$, the prosecutor in Case 2 references the victims by names much more frequently than the defense does. Informal labels predominate, with quite a few instances of nicknames (such as Zach vs. Zachary), as exhibited in Table 6.

In this case, the diminutive forms are used not only to personalize and individualize the victims, but also to convey a sense of intimacy and emphasize the smallness of the victims who were all children. Interestingly, this nomination strategy goes along with the use of age and size classification terms, as example (I3) shows:

(I3) The first witness you'll hear from is Brett ... Brett is also the oldest of the young men. You'll hear him say back in the nineties, you know, he went to a Second Mile event with the defendant and the defendant would want to do things with him. Brett was one of those kids that didn't have a father ... the defendant began, coerced, bred and cultivated with Brett because with Brett he was a big man, the defendant. Brett became the biggest football fan of all time. (Pro)

The defense's sparing use of names occurs in counter narratives. Contrast the defense's use of Brett in (I4) with the prosecution's above. Here the nickname is used to supply the identity of the noun phrase "Accuser No 4 " (which itself is a descriptive term that dehumanizes the victim).

(I4) In case of No. 4, Brett, you'll hear testimony ... he came over to Jerry and Dottie's ... But Brett, Accuser No 4, had brought his girlfriend and newborn baby over to see Jerry and Dottie ... looked like he was bringing his family to meet his father. (Def) 
TABLE 7

NOMINATION OF THE VICTIMS IN CASE 3

\begin{tabular}{llccc}
\hline & \multicolumn{1}{c}{ Prosecution } & Frequencies & Defense & Frequencies \\
\hline Informal (given name) & $\begin{array}{l}\text { Martin, Lingzi, Jane, } \\
\text { Henry, etc. }\end{array}$ & $15.95(12)$ & & - \\
$\begin{array}{l}\text { Semi-formal (given } \\
\text { and surname) }\end{array}$ & $\begin{array}{l}\text { Martin Richard, } \\
\text { Lingzi Lu, Dun Meng, etc. }\end{array}$ & $43.85(33)$ & Dun Meng & $8.68(2)$ \\
$\begin{array}{l}\text { Fr. Meng, Krystle Marie } \\
\text { Campbell }\end{array}$ & $21.26(16)$ & & Officer Collier \\
$\begin{array}{l}\text { Titulated formal } \\
\text { (title + last name) }\end{array}$ & $\begin{array}{l}\text { Officer Collier } \\
\text { Total }\end{array}$ & $17.28(13)$ & (3) \\
\hline
\end{tabular}

Case 3. In Case 3, as Table 7 demonstrates, the prosecution's use of nominations for the victims stands in stark contrast to the defense's. When introducing them into the narratives, the prosecution first uses semi-formal constructions and then switches to informal nominations as the storytelling continues, as in ( I 5 a). One particular victim, who was a campus police officer shot to death, is represented by the use of a title, as ( ${ }_{5} \mathrm{~b}$ ) shows:

( I 5a) One person the defendant murdered that day was Martin Richard ... The bomb tore large chunks of flesh out of Martin's body ... Martin bled to death ... Another person the defendant murdered that day is Lingzi Lu ... with her friend, Danling ... Lingzi was screaming in pain and terror, but Danling couldn't hear her because the bomb had deafened her. (Pro)

( 5 b) The defendant and his brother then murdered Officer Collier, carjacked, kidnapped, and robbed Dun Meng ... (Pro)

As compared to the prosecution, the defense avoids referencing the victims and rarely mentions their names. Her nominated references include only two victims, Dun Meng and Officer Collier, Even in these instances, they are represented as victims of the defendant's brother, as exemplified in (I6). Contrast this example with the prosecutor's representation in ( ${ }_{5} \mathrm{~b}$ ) above.

(I6) Tamerlan shot and killed Officer Collier. Tamerlan pointed the gun at Dun Meng, demanded his money ... (Def)

\section{Conclusion}

This analysis reveals systematic differences in referential practices along with pragmatic functions of naming choices in the narratives of courtroom lawyers. While the particular terms the opposing lawyers use for each defendant and victim differ from case to case, it appears that lawyers operate from a similar underlying awareness of how names can be manipulated to fulfill communicative goals. Shared patterns of naming strategies are identified across the cases. The prosecution creates social distance between the defendant and the jurors by 
rarely referencing him by name, thereby suppressing the defendant. In contrast to the defendants, the victims are individualized and personalized through informal nominated choices.

The defense employs different strategies. They personalize the defendants to a high degree by principally using first names. However, when it comes to referencing the victims, the defense is mainly silent. In addition, this study reveals that the opening is far from being a mere overview or road map of a particular case. Instead, it is a venue where identities are constructed and contested; and names are an integral part of this process.

In more theoretical terms, this study provides concrete evidence for the intertwined relationships between naming and identity work. In particular, it explicates the working of nominated terms in positioning social actors and managing the impressions of these actors, which in turn helps realize the speaker's communicative goals in institutional discourse. By viewing language as a system of choices from which to choose, this study offers insights into the relationship between the covert operations of naming choices and the speaker's underlying motivations, intentions, and goals that shape these choices.

The findings of this study have practical implications for training jurors and the public at large to be more aware and more critical of the power of seemingly insignificant but indeed powerful reference choices in constructing and shaping courtroom experiences. A future topic to be pursued is whether descriptive reference terms synergistically aid in the creation of competing identities of the same social actors.

\section{Notes}

I. Jurors are, at least theoretically, expected to know nothing at all about the case before the trial for reasons of impartiality.

2. Evidentials are grammatical expressions indicating whether the information was

obtained from seeing, hearing, inferring, or believing.

3. All the findings are presented as per Io,००० words.

\section{Bibliography}

Ainiala, Terhi, and Jan-Ola Ostman. 20I7. "Introduction: Socio-Onomastics and Pragmatics." In Socioonomastics: The Pragmatics of Names, edited by Terhi Ainiala and Jan-Ola Ostman, I-I 8. Amsterdam: John Benjamins.

Aldrin, Emilia. 2016. "Names and Identity." In The Oxford Handbook of Names and Naming, edited by Carole Hough, 382-394. Oxford: Oxford University Press.

Aldrin, Emilia. 20r 8. "Naming, Identity, and Social Positioning in Teenager's Everyday Mobile Telephone Interaction.” Names: A Journal of Onomastics. (in press)

Allerton, D.J. 1996. "Proper Names and Definite Descriptions with the Same Reference: A Pragmatic Choice for Language Users." Journal of Pragmatics 25: 62I-633.

Anchimbe, Eric. 20II. "On not Calling People by their Names: Pragmatic Undertones of Sociocultural Relationships in a Postcolony." Journal of Pragmatics 43: I472-I 483.

Bucholtz, Mary, and Kira Hall. 2005. "Identity and Interaction: A Sociocultural Linguistic Approach." Discourse Studies 7: 585-6I4.

Clayman, Steven. 2010. "Address Terms in the Service of Other Actions: The Case of News Interview Talk." Discourse and Communication 4: I6I-I 83 . 
Conley, Robin. 2016. Confronting the Death Penalty: How Language Influences Jurors in Capital Cases. Oxford: Oxford University Press.

D'hondt, Sigurd. 2010. "The Cultural Defense as Courtroom Drama: The Enactment of Identity, Sameness, and difference in Criminal Trial Discourse." Law \& Social Inquiry 35: 67-98.

De Fina, Anna. 2003. Identity in Narrative: A Study of Immigrant Discourse. Amsterdam: John Benjamins.

De Fina, Anna, Deborah Schiffrin, and Michael Bamberg, eds. 2006. Discourse and Identity. Cambridge: Cambridge University Press.

Dickey, Eleanor. 1997. "Forms of Address and Terms of Reference." Journal of Linguistics 33: 255-274.

Gerritzen, Doreen. 1999. "Changes in the Naming Patterns for Girls and Boys in the Netherlands against the Cultural Background (XXth Century)." Onoma 34: I8I-I95.

Halliday, M.A.K., and Ruqaiya Hasan. 1989. Language, Context, and Text: Aspects of Language in a Social-Semiotic Perspective. Oxford: Oxford University Press.

Hart, Christopher. 20II. "Legitimising Assertions and the Logico-Rhetorical Module: Evidence and Epistemic Vigilance in Media Discourse on Immigration.” Discourse Studies I 3: 75 I-769.

Levinson, Stephen. 2007. "Optimizing Person Reference: Perspectives from Usage on Rossel Island." In Person Reference in Interaction: Linguistic, Cultural, and Social Perspectives, edited by N.J. Enfield and Tanya Stivers, 29-72. Cambridge: Cambridge University Press.

Lind, Allen, and Gina Ke. I985. "Opening and Closing Statements." In The Psychology of Evidence and Trial Procedure, edited by Saul Kassin and Lawrence Wrightsman, 229-253. London: Sage.

Matoesian, Gregory. 200I. Law and the Language of Identity: Discourse in the William Kennedy Smith Rape Trial. Oxford: Oxford University Press.

McKinlay, Andrew, and Chris McVittie. 20Ir. Identities in Context: Individuals and Discourse in Action. London: Wiley-Blackwell.

Mondada, Lorenza. 2004. "L'annuncio del Nome del Paziente come Dispositivo Strutturante per L'attivita." Revista di Psicolinguistica Applicata 2: 65-78.

Murphy, Gregory. 1988. "Personal Reference in English." Language in Society I7: 3 17-349.

O’Barr, William. 1982. Linguistic Evidence: Language, Power, and Strategy in the Courtroom. New York: Academic Press.

Pennington, Nancy, and Reid Hastie. I99I. "A Cognitive Theory of Juror Decision Making: The Story Model." Cordoza Law Review I3: 5 I9-557.

Rosulek, Laura. 2008. "Manipulative Silence and Social Representation in the Closing Arguments of a Child Sexual Abuse Case." Text \& Talk 28: 529-550.

Rosulek, Laura. 2015. Dueling Discourses: The Construction of Reality in Closing Arguments. Oxford: Oxford University Press.

Schegloff, Emanuel. 2007. "Categories in Action: Person-Reference and Membership Categorization." Discourse Studies 9: 433-46I.

Spiecker, Shelley, and Debra Worthington. 2003. "The Influence of Opening Statement/Closing Argument Organizational Strategy on Juror Verdict and Damage Awards." Law and Human Behavior 27: 437-456. van Langendonck, Willy. 2007. Theory and Typology of Proper Names. Berlin: Mouton de Gruyter. van Leeuwen, Theo. 2008. Discourse and Practice: New Tools for Critical Discourse Analysis. Oxford: Oxford University Press.

\section{Notes on contributor}

Krisda Chaemsaithong is Professor of English at Hanyang University, where he teaches and supervises research in Discourse Analysis, Pragmatics, and Stylistics. Adopting methodology from these fields, his publications focus on courtroom discourse and examine such issues as identity construction, politeness, power relations, and interpersonal relationships.

Correspondence to: Krisda Chaemsaithong, Department of English Language and Literature, Hanyang University, 222 Wangsimni Road, Seongdong-Gu, Seoul, South Korea 047663. Email: krisda@hanyang.ac.kr 